\title{
PENGARUH KONSENTRASI PATI SAGU TERMODIFIKASI PADA PEMBUATAN PERMEN
}

\section{EFFECT OF MODIFIED SAGO STARCH CONCENTRATION ONCANDY MAKING}

\author{
Angcivioletta Moniharapon \\ Baristand Industri Manado \\ Jalan Diponegoro No.21-23 Manado \\ e-mail: moniharaponletta@yahoo.co.id \\ Diterima tgl 27-05-2016, Disetujui 01-06-2016
}

\begin{abstract}
ABSTRAK
Penelitian pemanfaatan pati sagu termodifikasi dalam pembuatan permen bertujuan untuk menghasilkan permen bertekstur lunak dengan memanfaatkan pati sagu termodifikasi. Tahapan proses yang dilakukan yaitu pembuatan pati sagu termodifikasi, pembuatan permen lunak, dan pengujian mutu permen. Metode yang digunakan adalah metode deskriptif. Permen lunak yang diperoleh pada penelitian memiliki rata-rata kadar air $20 \%$, abu $12 \%$, gula reduksi $8 \%$ serta secara organoleptik disukai panelis. Parameter yang diuji memenuhi syarat mutu SNI 3547.1:2008.

Kata kunci: konsentrasi, pati sagu termodifikasi, pembuatan permen
\end{abstract}

\section{ABSTRACT}

Utilization of modified sago starch to produce soft textured candies has been studied.The processwas conducted through preparation of modified sago starch, making of soft candy and quality testing of the products. Results of research were analyzed using descriptive method. The results showed that the products have an average of $20 \%$ of water, $12 \%$ of sugar reduction, and $8 \%$ of ash, which were accepted by panelists. The products were also met the quality requirements of SNI 3547.1: 2008.

Key words:consentration, modified sago starch, candy making

\section{PENDAHULUAN}

Tanaman sagu dengan bahasa latinMetroxylon sagu Rottboell, berarti tanaman yang menyimpan pati pada batangnya (Metro: empulur, xylon: xylem, sagu: pati). Tumbuhan dengan diameter batang dapat mencapai $60 \mathrm{~cm}$ dengan panjang $25 \mathrm{~m}$ ini menimbun pati didalamnya melalui proses fotosintesis(1). Pati tersebut digunakan secara luas dalam industri pangan, baik sebagai bahan baku maupun bahan tambahan sebagai pengental, pembentuk gel, pembentuk film dan penstabil. Penggunaan pati alami menyebabkan beberapa permasalahan yang berhubungan dengan retrogradasi, sineresis, kestabilan rendah, dan ketahanan pasta yang rendah terhadap $\mathrm{pH}$ dan perubahan suhu.Untuk memperbaiki sifat-sifat dari pati alami, maka pati perlu untuk dimodifikasi sehingga menghasilkan karakteristik produk pangan yang diinginkan.

$$
\text { Pati termodifikasi banyak }
$$
digunakan dalam bidang pangan yaitu pembuatan salad cream, mayonnaise, saus kental, serta produk-produk konfeksioneri seperti permen.Permen merupakan salah satu produk pangan yang cukup digemari segala kalangan. Umumnya jenis makanan selingan ini dibuat dari gula dengan penambahan rasa maupun warna dengan bentuk yang padat dengan atau tanpa tambahan bahan pangan lain yang diijinkan, sehingga bertektur relatif lunak atau menjadi lunak jika dikunyah. Untuk membuat permen dengan tekstur yang 
lunak, berdasarkan SNI 3547.2-2008 (Kembang Gula: Lunak), maka perlu ditambahkan komponen hidrokoloid diantaranya pati, untuk modifikasi tekstur sehingga menghasilkan produk yang kenyal.

Pati termodifikasi adalah pati yang telah mengalami perubahan fisik atau kimia secara terkendali sehingga mengubah satu atau lebih dari sifat asalnya seperti suhu awal gelatinisasi, karakteristik, selama proses gelatinisasi, ketahanan oleh pemanasan, pengasaman dan pengadukan dan kecenderungan retrogradasi. Perubahan yang terjadi pada level molekuler dengan atau tanpa mengubah penampakan dari granula pati. Setiap metode modifikasi akan menghasilkan pati termodifikasi dengan sifat yang berbedabeda. Wurzburg, mengatakan hal ini dilakukan untuk mengubah sifat kimia dan atau sifat fisik dari pati secara alami, yakni dengan cara pemotongan struktur molekul pati(2). Tujuannya menghasilkan sifat yang lebih baik untuk memperbaiki sifat sebelumnya atau untuk merubah beberapa sifat lainnya. Kusnandar, 2010 dalammenekankan teknik modifikasi pati secara hidrolisis asam, menghasilkan pati sagu dengan viskositas yang rendah sehingga dapat diaplikasikan pada pembuatan produk confectionary (permen/gum)(3).

Permen adalah sejenis gula-gula (confectionary) yang dibuat dengan mencairkan gula didalam air.Perbedaan tingkat pemanasan menetukan jenis permen yang dihasilkan, suhu panas menghasilkan permen keras, suhu menengah menghasilkan permen lunak, dan suhu dingin menghasilkan permen kenyal.Permen dinikmati karena rasa manisnya(4). Permen adalah jenis makanan selingan berbentuk padat, dibuat dari gula atau pemanis lain atau campuran gula dengan pemanis lain dengan atau tanpa penambahan bahan makanan lain dan bahan tambahan makanan yang diijinkan.

Penelitian ini bertujuan untuk menghasilkan permen berteksurlunak dengan memanfaatkan pati sagu termodifikasi.

\section{BAHAN DAN METODE}

\section{Bahan dan Alat}

Bahan utama yang digunakan dalam penelitian ini adalah pati sagu termodifikasi dan bahan pembantu lainnya seperti glukosa, gula pasir, asam sitrat, flavor nanas, tepung gula pasir, tepung maizena, air mineral serta bahan-bahan kimia lainnya untuk analisis.

Peralatan yang digunakan yaitukompor gas, timbangan digital, compact infrared thermometer, oven, buret, cawan petri.

\section{Rancangan Penelitian}

Penelitian ini dilaksanakan secara deskriptif dengan pengamatan uji kimiayakni:kadarair, kadar abu, gula reduksi; organoleptik: tekstur, rasa dan penampakan. $\quad U j \mathrm{j}$ organoleptik menggunakan skala hedonik yaitu skala 1-5 dimana 5 (sangat suka), 4 (suka), 3 (agak suka), 2 (tidak suka), 1 (sangat tidak suka).

\section{Pembuatan Pati Termodifikasi}


Prosedur pembuatan pati termodifikasi diawali dengan penimbangan pati sagu sebanyak 100gram, selanjutnya disemprotkan dengan katalis $\mathrm{HCl} 0.3 \mathrm{M}$ dengan menggunakan sprayer(5). Diaduk agar katalis tercampur rata dengan tepung sagu.Langkah berikutnya dipanaskan pada oven suhu $120^{\circ} \mathrm{C}$ dengan lama pemanasan 2 jam. Produk didinginkan dengan cara diangin-anginkan lalu dianalisis mutunya. Lihat Gambar 1 untuk proses termodifikasinya. Produk dekstrin pati sagu dengan cara kering menggunakan konsentrasi $\mathrm{HCl}$ 8\% dan lama pemanasan 2 jam, menghasilkan dekstrin pati sagu yang memenuhi Standar Nasional Indonesia dekstrin untuk industri pangan, yakni kadar air $1.66 \%$, kadar abu $0.08 \%$, $\mathrm{pH} 2.59$, kadar dekstrosa $3.80 \%$ dan bagian yang larut dalam air dingin $99.57 \%$. Namun tahap ini, tidak akan diulas lebih jelas nilai uji mutu yang diperoleh, dikarenakan tidak adanya perlakuan prosentase $\mathrm{HCl}$ yang digunakan. Hanya diambil dasar acuan teori dari penelitian sebelumnya dalam proses termodifikasi.

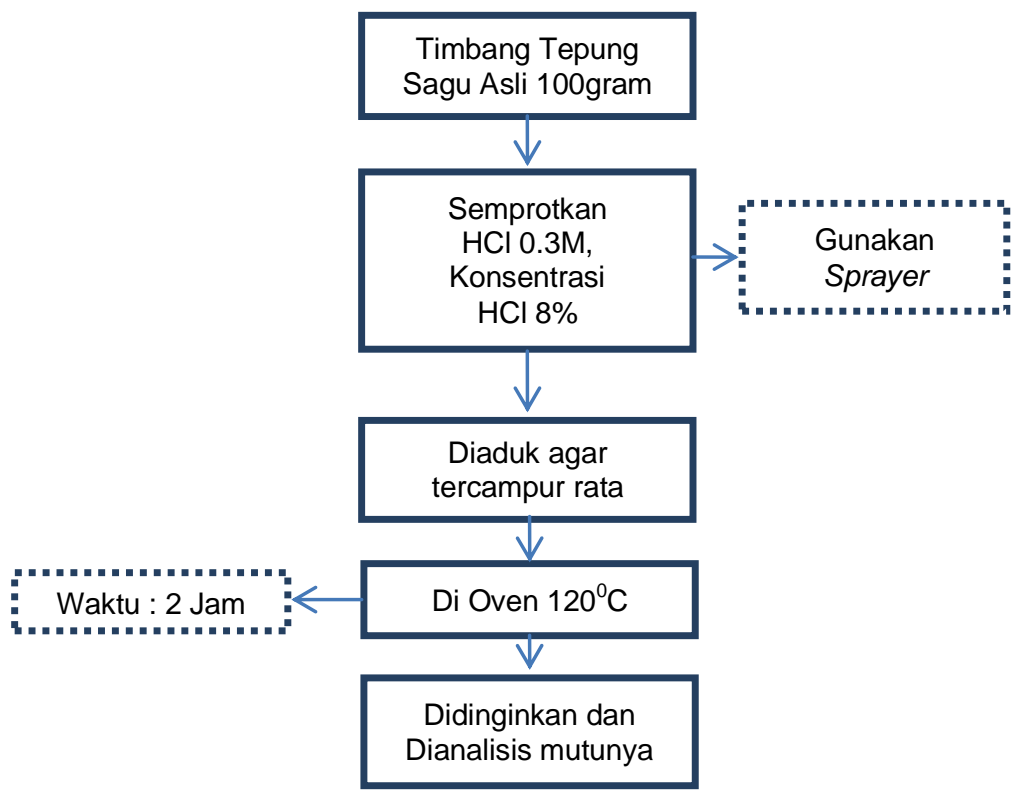

Gambar 1. Proses Pembuatan Tepung Sagu Termodifikasi HCl (5).

\section{Pembuatan Permen Lunak}

Prosedur pembuatan permen
bertekstur lunak diawali dengan
penimbangan Tepung Sagu Termodifikasi (Ts) dan Gelatin (G) berjumlah 7\% yang terdiri dari uji kimiadan uji organoleptik dengan kode Ts2G5:Ts=2\%,G=5\%; Ts3G4:Ts=3\%,G=4\%; Ts4G3:Ts=4\%, G=3\%; dan Ts5G2: Ts=5\%,G=2\%dimana nilai komposisi bahan lainnya yang konstan yakni sukrosa dan glukosa $45 \%$ dan $20 \%$, flavor $1 \%$, asam sitrat0,3\% dan air $26,7 \%$. Komposisi lengkapnya lihat tabel 5.Langkah selanjutnya, pati dan gelatin direndam dalam air mineral kira-kira 5 menit, lalu diaduk dan dimasak dalam panci.Masak sampai suhu mencapai 60$70^{\circ} \mathrm{C}$.Kira-kira semenit kemudian lakukan penambahan secara berurut sukrosa, sirup glukosa, dan asam sitrat.Aduk sampai larut dan masak hingga suhu mencapai $90^{\circ} \mathrm{C}$, 
Ialu dilanjutkan dengan penambahan flavor.Adonan segera dimasukan pada cetakan. Dinginkan pada suhu ruang selama 1 jam untuk kemudian disimpan pada suhu $5-10^{\circ} \mathrm{C}$ selama 24 jam. Permen dikeluarkan dari lemari pendingin, setelah sejam dipotong-potong dan digulingkan pada bahan pelapis.Bahan ini terdiri atas tepung maizena dan tepung gula pasir, komposisinya 1:1. Proses pembuatan permen lunak dapat dilihat pada Gambar 2

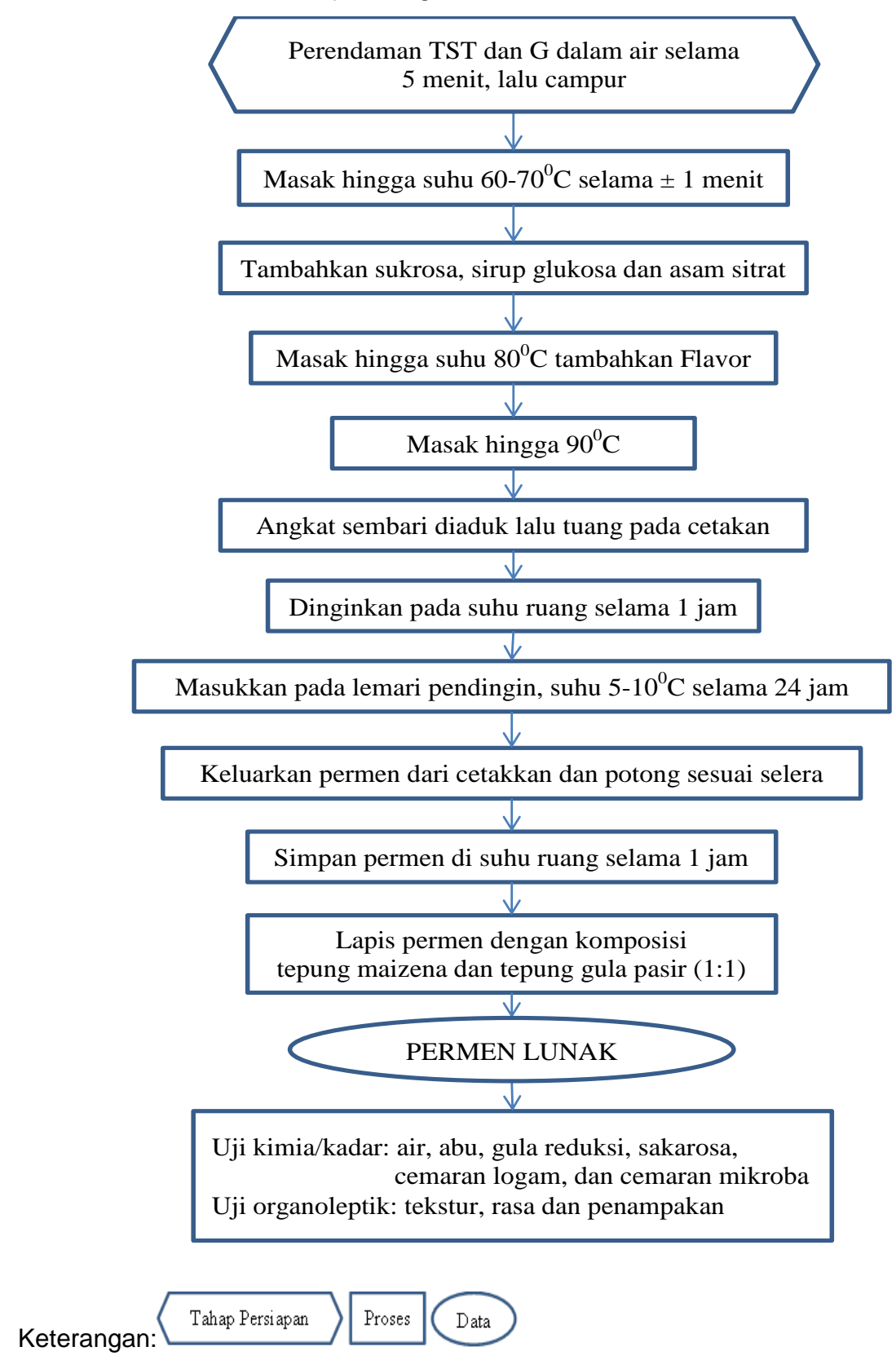

Gambar 2. Proses Pembuatan Permen Lunak dari Pati Sagu Termodifikasi(6).

HASIL DAN PEMBAHASAN

\section{Kadar Air}


dengan penambahan pati modifikasi $5 \%$, tidak jauh berbeda nilainya dengan penambahan gelatin $5 \%$ pula. Hal ini terjadi karena pati sagu telah dimodifikasi, hingga sifat awalnya (kimia dan fisik) mempunyai karakter yang dikehendaki, ditunjang dengan karakteristik granula pati akan sangat berpengaruh didalamnya (kimia dan fungsional pati)(7).

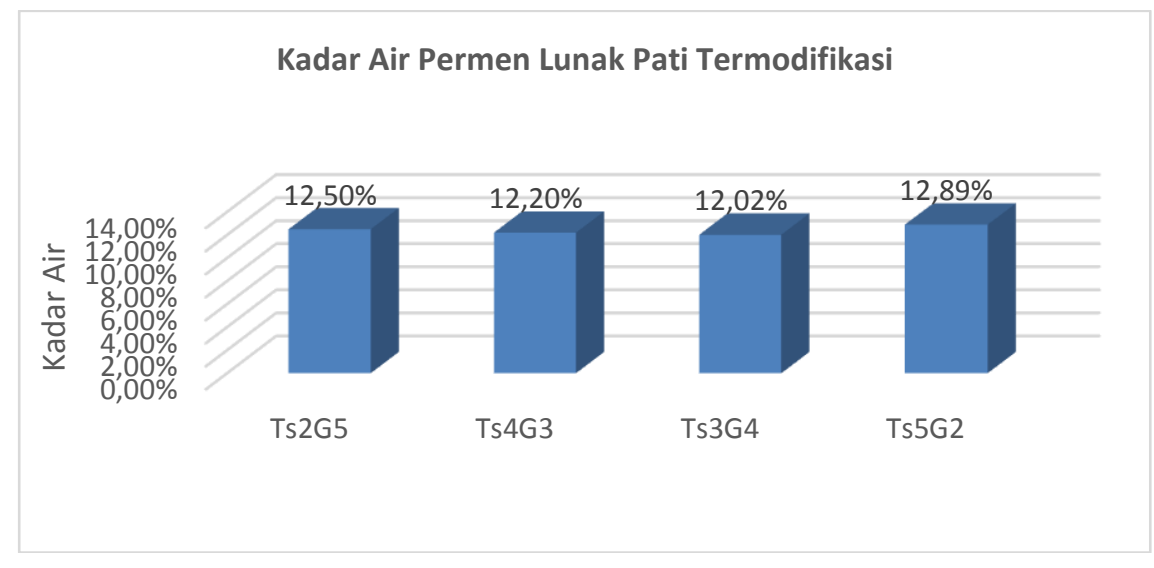

Gambar 3. Diagram Batang Nilai Kadar Air Permen Lunak Pati Termodifikasi

Proses gelatinisasi terjadi apabila granula pati dipanaskan didalam air, maka energi panas yang timbul menyebabkan ikatan hidrogen terputus dari air lalu masuk ke granula pati kemudian granula mengembang dan pecah. Hal ini terjadi karena jumlah gugus hidrolisis dalam molekul pati sangatlah besar, maka kemampuan menyerap air pun sangat besar pula(8).

Winarno menambahkan gelatinisasi sebagai peristiwa koagulasi koloid yang mengakibatkan terperangkapnya air(9). Pembentukan gelatinisasi dalam bidang pangan mengambil peran dalam pembuatan permen.Kadar air yang diperoleh memenuhi standar yang ditetapkan SNI 3547.1:2008 yaitu sebesar $20 \%$.

\section{Kadar Abu}

Kadar ini menjelaskan seberapa besar minimal yang tidak terbakar menjadi zat yang mudah menguap(6). Pada Gambar 4 kadar abu, gelatin $2 \%$ nilai kadar abunya $0,28 \%$ dan pati termodifikasi $2 \%$ yang ditambahkan nilainya $0,15 \%$. Begitupun dengan gelatin $4 \%$ nilainya $0,18 \%$, serta pati termodifikasi $\quad 4 \%$ sebesar $0,11 \%$.

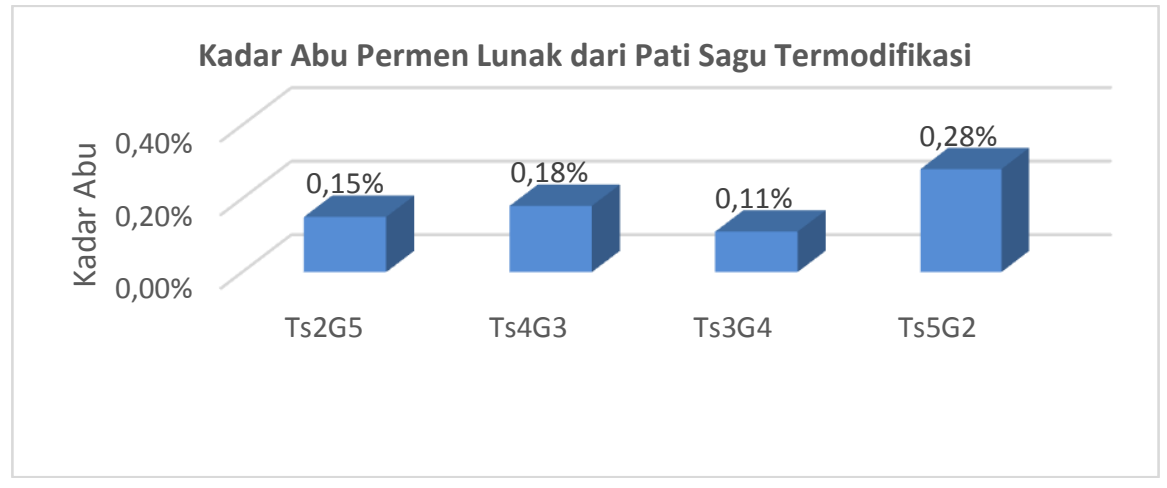




\section{Gambar 4. Diagram Batang Nilai Kadar Abu Permen Lunak Pati Termodifikasi.}

Nilai kadar ini masih memenuhi syarat SNI (2008) yaitu sebesar 3\%. Nilai ini merupakan salah satu parameter yang digunakan untuk melihat kualitas dan tingkat keberhasilan pati modifikasi. Kadar abu hasil penelitian ini memiliki nilai yang rendah menunjukkan bahwa proses pengadukan pati dan gelatin lebih maksimal sehingga hasil penelitiannya baik.

\section{Gula Reduksi}

Kadar gula reduksi yang dihasilkan pada permen lunak berkisar 7.768.70\%.Tertinggi pada perlakuan kosentrasi gelatin $3 \%$ dengan $45 \%$ sukrosa terendah pada gelatin $2 \%$ (Gambar 5 ).

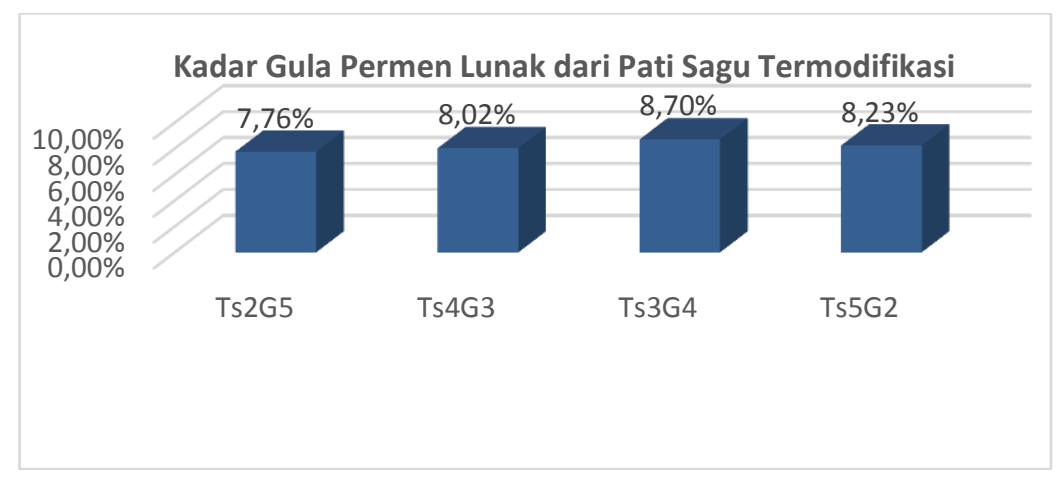

Gambar 5. Diagram Batang Nilai Kadar Gula Permen Lunak Pati Termodifikasi

Winarno menjelaskan peningkatan gula pereduksi disebarkan selama proses pendidihan larutan sukrosa(10). Larutan ini mengalami verse atau pemecahan menjadi glukosa dan fruktosa akibat pengaruh asam dan panas yang akan meningkat pada larutan gula tersebut. Kadar gula reduksi yang dihasilkan pada penelitian permen ini memenuhi standar mutu SNI 3547.1:2008 tentang Permen Lunak.

\section{Uji Organoleptik}

Uji organoleptik merupakan faktor penting yang mempengaruhi diterima atau tidak suatu produk makanan oleh konsumen. Uji pada penelitian ini menggunakan Penilaian Tingkat Kesukaan: 1=sangat tidak suka, 2=tidak suka, 3=agak suka, 4=suka, dan $5=$ sangat suka.

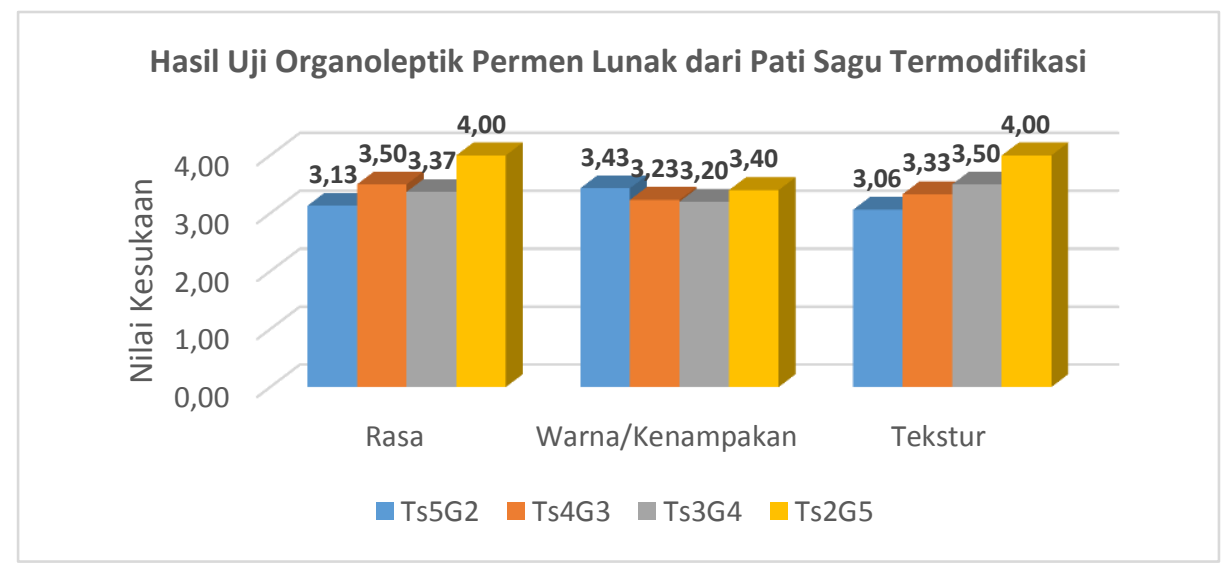




\section{Gambar 6. Diagram Batang Hasil Uji Organoleptik Permen Lunak dari Pati Sagu Termodifikasi Rasa}

Uji ini merupakan salah satu faktor penting yang mempengaruhi diterima atau tidak oleh konsumen pada suatu makanan.Walaupun nantinya jika warna dan tekstur dari suatu makanan (permen) nilainya baik (disukai) namun nilai rasa sebaliknya, maka makanan tersebut tidak diterima oleh konsumen.

Berdasarkan hasil penelitian dan analisisnya menunjukkan bahwa penambahan gelatin berpengaruh terhadap penilaian nilai organoleptik rasa ini.Rata-rata kesukaan panelis terhadap rasa permen jelly bervariasi dengan nilai berkisar 3.13 (agak suka) sampai 4 (suka).

Perlakuan yang menghasilkan rasa disukai adalah penambahan gelatin 5\%. Penambahan ini menghasilkan rasa permen jelly disukai konsumen.Semakin banyak gelatin yang ditambahkan maka jumlah air yang terperangkap dalam molekul-molekul gelatin semakin besar. Ini membuat permen agak keras dan kekenyalan gel terbentuk akibat penambahan gelatin yang melebihi $5 \%$.Gel terbentuk akibat ikatan hidrogen antara molekul gelatin. Kekuatan gel gelatin akan mempengaruhi elastisitas suatu produk.

\section{Warna/Kenampakan}

Warna memiliki peran penting pada komoditas pangan.Semakin pentingnya nilai ini karena dapat menjadi daya tarik, tanda pengenal dan atribut mutu dari suatu produk. Soekartomenambahkan penilaian secara subjektif masih sangat menentukan(11). Hal ini dikarenakan faktor paling cepat dan mudah memberi kesan namun sulit cara pengukurannya.
Gelatin yang baik menurut standar yakni tidak berwarna, transparan, dan tidak beraroma. Imerson menambahkan penggunaan gelatin nantinya tidak akan mempengaruhi warna/kenampakan suatu produk(2).

Hasil uji menunjukkan pada Gambar 6 penambahan gelatin dan pati termodifikasi tidak memberikan pengaruh terhadap warna permen jelly yang dihasilkan. Nilai rata-rata berkisar 3.2 (agak suka)-3.43 (agak suka).Hal ini diduga karena gelatin yang digunakan dalam kosentrasi relatif sedikit.

\section{Tekstur}

Hasil uji organoleptik spesifikasi tekstur untuk permen jelly berkisar 3,06-4. Hasil ini menunjukkan bahwa permen dengan penambahan prosentasi gelatin yang besar, nilai teksturnya lebih tinggi dibanding sebaliknya. Jones membenarkan hal tersebut, semakin tinggi presentase gelatin yang ditambahkan menyebabkan tekstur permen jelly semakin keras(12).

Sesuai dengan kemampuan daya kunyah, panelis-panelis lebih menyukai tekstur yang elastis dan tidak terlalu kenyal. Hal ini pun diungkap oleh Purnomo karena konsumen lebih menyukai permen jelly yang agak basah serta mdah kunyah dan teksturnya elastis(13).

Hal senada diungkap oleh Hemtani bahwa salah satu faktor terpenting dalam pembentukan gel adalah kosentrasi gelatin yang terlalu rendah, tekstur yang dihasilkan semakin lunak(14). Namun sebaliknya jika kosentrasi gelatinnya sangat tinggi maka permen bertekstur karet. 


\section{KESIMPULAN DAN SARAN}

\section{Kesimpulan}

Hasil penelitian pengaruh konsentrasi pati sagu termodifikasi pada pembuatan permen lunak ini diperolah data rata-rata kadar air $20 \%$, abu $12 \%$ dan gula reduksi $8 \%$ serta memiliki tingkat kesukaan penampakan (netral), rasa (suka), dan tekstur (suka) sehingga masih diterima oleh panelis.

\section{Saran}

Perlu dilakukan penelitian lanjutan bermutu terhadap tingkat kesukaan, penambahan bahan hidrokoloit lain, waktu penyimpanan, dan pengemasan produk. Selain itu perlu dilakukan pemanfaatan pati termodifikasi dari bahan lainnya sehingga khasanah ilmu pengetahuan makin bertambah.

\section{DAFTAR PUSTAKA}

1. Flach M. A simple growth model for sago palm cv. Molat-Ambutrub. And It's Application for Cultivativation. Abstracts of the Eight International Sago Symposium in Jayapura, Indonesia: Japan Soc Promot Sci; 2005.

2. Herawaty $\mathrm{H}$. Teknologi proses produksi food ingerdient dari tapioka termodifikasi. Litbang Pertanian, Balai Besar Pertan dan Pengemb Pascapanen Pertan Bogor. Bogor: 2013;70.

3. Bastian F. Teknologi pati dan gula. In: Buku ajar teknologi pati dan gula. Makassar: Program Studi Ilmu dan Teknologi Pangan, Jurusan Teknologi Pertanian, Fakultas Pertanian, Universitas Hassanudin; 2011.

4. Anonim. Permen dinikmati karena rasa manis. In: Wikipedia Indonesia, Ensiklopedia Berbahasa Indonesia; 2007.

5. Lintong $\mathrm{H}$. Produksi dekstrin dari pati aren dengan cara kering. Universitas Sam Ratulangi Manado; 2011.

6. Damayanti D. Aplikasi gelatin dari tulang ikan patin pada pembuatan permen jelly. Institut Pertanian Bogor. Bogor; 2007.

7. Wursberg O. Modified starchers. CRC Press Inc; 1986.

8. Chaplin. Gugus hidrolisis pati.2006.diakses dari:

https://tonimpa.wordpress.com/laporan/biote knologi/hidrolisis-pati-secara-enzimatis/.

[Internet]. Google.. Diakses tanggal: 2015 Mar 15.

9. Winarno F. Kimia pangan dan gizi. Jakarta: PT. Gramedia; 2004.

10. Winarno F. Kimia pangan dan gizi. Jakarta: PT. Gramedia; 2008.

11. Hayati R, Yusmanizar, Fauzi H. Pengaruh fermentasi dan suhu pengeringan pada mutu biji kakao (Theobroma Cacao L). Banda Aceh;

12. Jones N. Use Of Gelatin in Edible Product. In: Use Of Gelatin In Edible Products In: AG Ward and A Courts (ed). New York: Academyc Press; 1977. p. 366-92.

13. Purnomo H. Aktifitas air dan peranan dalam pengawetan pangan. Jakarta: UI Press; 1995.

14. Hemtani R. Aplikasi gelatin tipe a dalam pembuatan permen mangga. Institute Pertanian Bogor; 2002. 